\title{
Interactive media of respiratory system material "resysmart" based on problem-based learning
}

\author{
Luthfi Rahayu Ningsih a,1,* Mieke Miarsyah a,2, R. Rusdi a,3 \\ a Department of Biology Education, Faculty of Mathematics and Natural Science, Universitas Negeri Jakarta, Jl. Rawamangun Muka, \\ the Special Capital Territory of Jakarta (DKI, Jakarta) 13220, Indonesia \\ ${ }^{1}$ luthfi.rahayuningsih@gmail.com * ${ }^{2}$ mmiarsyah@unj.ac.id, ${ }^{3}$ rusdi@unj.ac.id \\ * Corresponding author
}

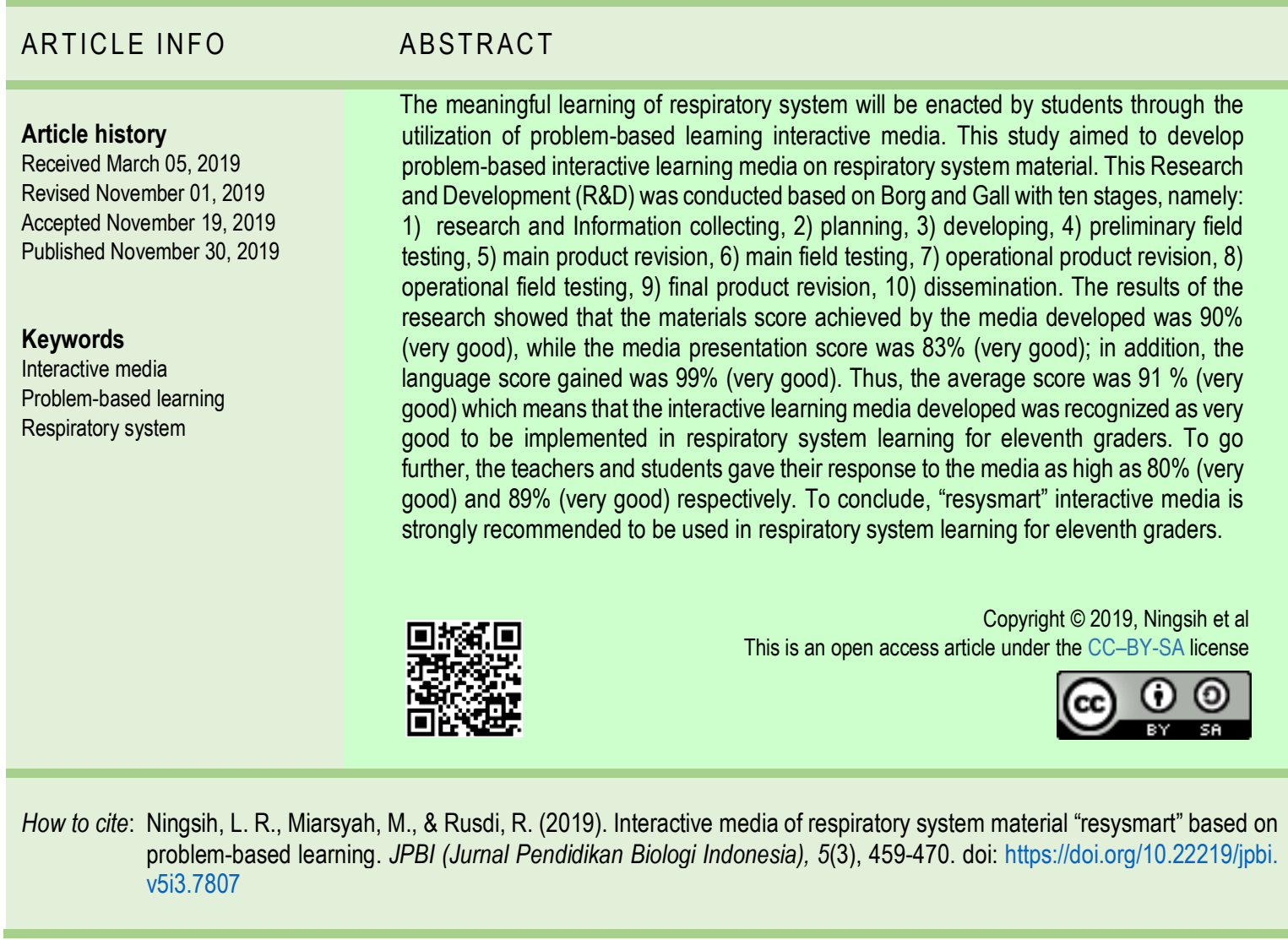

\section{INTRODUCTION}

Education, which is scientific knowledge, always has continuous development. Similarly, the definition of schooling always develops from the past. The modern description of education is the process of awareness of students that occurs because of the interaction of various factors concerning humans, the environment, and the potential and possibilities in it (Agustina, Kristiyanto, \& Noviandini, 2017). According to Wyness \& Dalton (2018), education is all learning experiences that take place in all environments and throughout life.

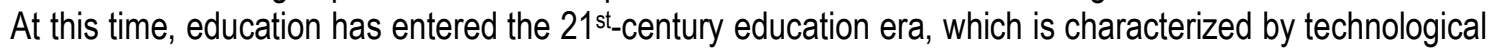
advances and demands that students must have soft skills in facing the real world. The $21^{\text {st-century capability }}$ according to engage consists of digital-age literacy, inventive thinking, effective communication, high productivity (Astra, Nasbey, \& Nugraha, 2015; Mason, 2006). In this 21 st-century, capability must be prepared 
in schools through the learning process, so that students can compete in the $21^{\text {st-century. Learning is a series }}$ of activities that are planned by the teacher and directed at specific learning outcomes (Tran, Ho, Mackenzie, \& Le, 2017). In designing the learning process, the teacher needs to develop learning objectives, of course, must consider various dynamic elements that can influence learning. The active components in the learning process are learning motivation, teaching materials, teaching aids, learning atmosphere, and learning subject conditions (Dunn \& Kennedy, 2019; Liu, Du, Zhang, \& Zhou, 2019). The selection of media tailored to the objectives, material, and abilities and characteristics of students will significantly support the process and learning outcomes (Chen, 2008; Donnelly, 2010; Zhang, Zheng, Li, \& Tian, 2012).

One of the things that must be considered by a teacher in achieving learning objectives is the selection of learning media. The word media comes from Latin, which is the plural form of the medium means an intermediary (Gao \& Huang, 2019; Miklos, 2019). In other definitions, media can be interpreted as an intermediary for delivering messages from informants to recipients of information. According to Dring (2019), the media can be in the form of materials (software) or tools (hardware). From these definitions when associated with learning, the media is an intermediary that can deliver students in achieving learning goals.

Teachers can choose many learning media, either visual, audio, or kinesthetic based. However, one type of media has not been able to accommodate all students with diverse levels of character and intelligence. Therefore, teachers have to combine various types of media. Along with technological developments, teachers need to innovate in the selection of learning media. One form of innovation in teaching media is with multimedia learning media (Anderson \& Davidson, 2019; Beemt, Akkerman, \& Simons, 2011). One example of the application of multimedia is the use of adobe flash applications. Adobe Flash provides tools that can create interactive and varied applications (Beltramo, 2017; Copenhaver \& Ferguson, 2018). The learning media that will be developed are included in the category of interactive multimedia, which is a multimedia media equipped with a controller that can be operated by the user, so that the user can choose what will be done next (Chen, 2008; Hong, Lin, \& Lee, 2019; Kerkhoff, 2017).

Based on the initial data collection was obtained, $86.8 \%$ of students stated that learning media was influential in biology learning, as many as $100 \%$ of teachers noted the same thing. $72.1 \%$ of students indicated that the most suitable learning media for biology subjects was learning media that included sounds, images, and videos. However, in reality, in the schools, $70.6 \%$ of students state that the biology learning media that is often used by teachers is PowerPoint media. Therefore, it is necessary to develop biology learning media, which includes sounds, images, and videos.

The material in this study is the respiratory system in humans. The goals of respiration are to provide oxygen to the tissues and to remove carbon dioxide (Donnelly, 2010; Klunklin, Subpaiboongid, Keitlertnapha, Viseskul, \& Turale, 2011).The selection of respiratory system material is based on the fact that smoking activities among adolescents are very alarming. Based on data obtained from the main results of Riskesdas (the Ministry of Health of the Republic of Indonesia in 2018 states) that the trend of increasing child smokers (ages 10-18 years) is increasing from 2007 to 2018 . Therefore education in learning is needed as a reminder of the dangers of smoking in the respiratory system.

Based on the results of the initial data collection, data obtained that amounted to $11.8 \%$ of the dominant smoking students started since they were in elementary school. The teacher justifies this that they often find students who are smoking, even outside the school area. In the respiratory system material, there is a section that discusses the dangers of smoking to the health of human respiratory organs. So, the material of the respiratory system needs to be taught to students as a means of education in the socialization of the dangers of smoking to human health, so that it is expected to reduce the number of smokers who come from adolescents.

This study aims to develop adobe flash-based interactive learning media on respiratory system material, named Resysmart. This media is equipped with video problems so that it can stimulate students to think critically and be able to solve problems in daily life related to the respiratory system so that it can be used in collaboration with Problem Based Learning (PBL) Model. The syntax of the Problem Based Learning model, namely (1) identifying problems; (2) establishing issues through thinking about topics and selecting relevant information; (3) developing solutions through identifying alternatives, brainstorming and checking differences of opinion; (4) performing strategic actions; and (5) looking back and evaluating the effects of the solutions made (Agustina et al., 2017; Klunklin et al., 2011). It is expected that after learning using this learning, media can foster awareness of students about the dangers of smoking in the respiratory system. This learning media also contains problem exercises so that this media becomes an interactive media that can enhance students' enthusiasm for learning and motivation. 


\section{METHOD}

This research is development research with the model of Borg \& Gall (1983). The stages of research carried out can be seen in Table 1. The sample used was students of the eleventh grade of High School from State Senior High School (Sekolah Menengah Atas NegerilSMAN) 3 Cibinong, Bogor Regency, and Indonesia, which were taken by purposive sampling. The sample used for the study was 60 students and three biology teachers. I am retrieving data using questionnaires filled by material experts, linguists, media experts, teachers, and students. The expert validation instrument used to assess the quality of instructional media.

Table 1. The steps for developing the media

\begin{tabular}{|c|c|c|c|}
\hline Step & Objective & Activity & Note \\
\hline $\begin{array}{l}\text { Collecting } \\
\text { information }\end{array}$ & $\begin{array}{l}\text { Identify needs in } \\
\text { learning }\end{array}$ & $\begin{array}{l}\text { Distribute questionnaires to students and } \\
\text { teachers }\end{array}$ & $\begin{array}{l}\text { Teachers and students as respondents, } \\
\text { questionnaires as instruments for } \\
\text { gathering information }\end{array}$ \\
\hline Planning & $\begin{array}{l}\text { Planning learning } \\
\text { devices to be used } \\
\text { creating a learning plan }\end{array}$ & $\begin{array}{l}\text { Making material outlines to be poured in } \\
\text { learning media, compiling the tests to be } \\
\text { used }\end{array}$ & $\begin{array}{l}\text { Material analysis and storyboard } \\
\text { preparation }\end{array}$ \\
\hline Developing & $\begin{array}{l}\text { Develop learning } \\
\text { devices }\end{array}$ & $\begin{array}{l}\text { Develop a learning plan using the problem } \\
\text { based learning model. } \\
\text { Develop learning media using adobe flash }\end{array}$ & Prototype and assessment instruments \\
\hline $\begin{array}{l}\text { Trying out } \\
\text { prototype }\end{array}$ & $\begin{array}{l}\text { Feasibility test by } \\
\text { experts }\end{array}$ & $\begin{array}{l}\text { Conduct test of content, material and } \\
\text { language feasibility by experts }\end{array}$ & $\begin{array}{l}\text { Experts from experts according to their } \\
\text { respective fields }\end{array}$ \\
\hline Revise & Improve the product & $\begin{array}{l}\text { Revise learning media according to input } \\
\text { from revised prototype }\end{array}$ & Revised prototype \\
\hline $\begin{array}{l}\text { A small group } \\
\text { tryout }\end{array}$ & $\begin{array}{l}\text { Trial small group of } \\
\text { students }\end{array}$ & Conduct trials on small groups of students & There are 8 students \\
\hline Revise & Improve the product & $\begin{array}{l}\text { Revise learning media based on the results } \\
\text { of the trial }\end{array}$ & Revised prototype \\
\hline A field trial & Trial in large groups & Conduct trials on large groups of students & There are 30 students \\
\hline Revise & Improve the product & $\begin{array}{l}\text { Revise learning media in accordance with } \\
\text { the results of the trial }\end{array}$ & Revised prototype \\
\hline Dissemination & Product dissemination & Socialize learning media to biology teachers & $\begin{array}{l}\text { Learning media products using adobe } \\
\text { flash }\end{array}$ \\
\hline
\end{tabular}

The instrument is made using a Likert scale, with five answer choices. The results of the answers are then searched for averages using the relative frequency distribution Formula 1 (Sudijono, 2005), where "f" is the frequency that will be searched for, " $\mathrm{N}$ " is a number of frequencies, and "P" is percentage number.

$\mathrm{P}=\frac{f}{N} \times 100 \%$

The limit of the assessment of whether or not the learning media of the respiratory system to be used as an alternative learning media is based on the interpretation criteria of scores for the Likert scale (Klunklin et al., 2011), namely: $5 \%$ - 24\% (very not good), $25 \%$ - 49\% (not good), 50\% - 74\% (good), dan $75 \%$ - 100\% (very good).

\section{RESULTS AND DISCUSSION}

The effectiveness of learning media developed depends on the extent to which the learning media can accommodate curriculum needs, educational institutions, and students by the expected material and competencies (Wyness \& Dalton, 2018). To find out these needs, the first stage of this study was conducted, namely the collection of initial data in the form of questionnaires for learning media needs that are suitable for biology. Based on the data obtained, $86.8 \%$ of students stated that learning media was influential in biology learning, as many as $100 \%$ of teachers noted the same thing. $72.1 \%$ of students noted that the most suitable learning media for biology subjects was learning media that included images, videos, and sounds. However, in the reality that occurs in schools, $70.6 \%$ of students state that the biology learning media that is often used by teachers is PowerPoint media. Therefore, it is necessary to develop biology learning media, which includes images, videos, and sounds. 
The material selection of the respiratory system is based on the fact that smoking is very close to the lives of teenagers. Based on the results of the initial data collection, data obtained that amounted to $11.8 \%$ of the dominant smoking students started since they were in elementary school. The teacher justifies this that they often find students who are smoking, even outside the school area. In the respiratory system material, there is a section that discusses the content of cigarettes to the dangers of smoking to the health of human respiratory organs. So, the material of the respiratory system needs to be taught to students as a means of education in the socialization of the dangers of smoking to human health, so that it is expected to reduce the number of smokers who come from adolescents.

After the initial data collection, the next step is to design the product. This product is designed according to the basic competence of the respiratory system in class XI. In developing learning media, things that need to be considered are the goals to be achieved, characteristics of students/targets, types of desired learning stimuli (audio, visual, motion), the state of the local environment, and the extent of the range to be served (Harris \& Andrews, 2008; Miklos, 2019). The interactive learning media of the respiratory system developed include video problems, human respiratory system material, animal respiratory systems, and general information. In addition, this media is also equipped with practice questions, so that this learning media could be said to be interactive media. Interactive media is a medium that involves two-way communication (Hong et al., 2019; Lau \& Mak, 2004; Tran et al., 2017).

On the menu, the human respiratory system consists of sub-menus of respiration devices, respiratory mechanisms, respiratory diseases, and cigarettes. On the list, the animal respiratory system consists of the respiratory system in birds and insects. Besides, there is also general knowledge about the respiratory system, which contains facts in everyday life regarding the respiratory system. After the design is made, the next is applying the design into a learning medium, using the adobe flash cc application.

Display of the interactive media of the respiratory system on the first prototype, among others: (1) initial view; (2) display of video problems; (3) menu display; (4) display of the human respiratory system; (5) display of the animal respiratory system; (6) display of general knowledge; and (7) display of the practice question. In the first prototype, the initial view informs the subject's identity is material title and level of education (Figure 1A). In the initial display after revision, there are no changes. This section informs the subject's identity, material title, and level of education (Figure 1-B). In the first prototype, the model in this video was unhidden. A video of problems in the form of smoking activities and vehicle fumes in the surrounding area is raised (Figure 2-A). In the final prototype, a video section of the problem, there is a revision regarding the addition of the previous button to return to the initial view, and the model was hidden (Figure 2-B).

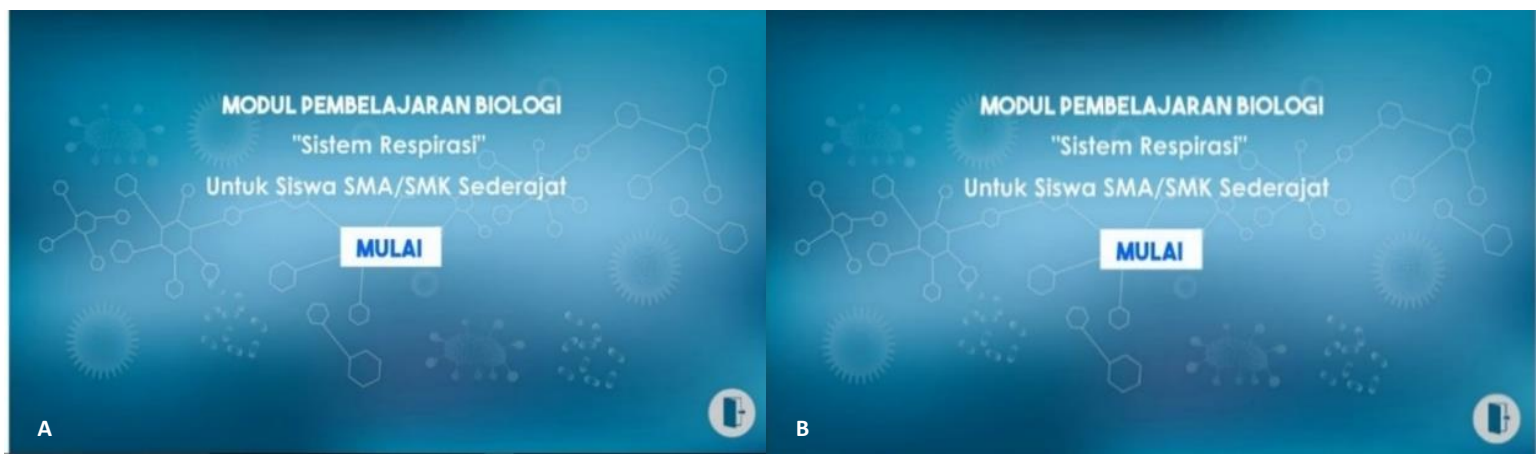

Figure 1. (A) Initial view (first prototype); (B) Initial view (final prototype)

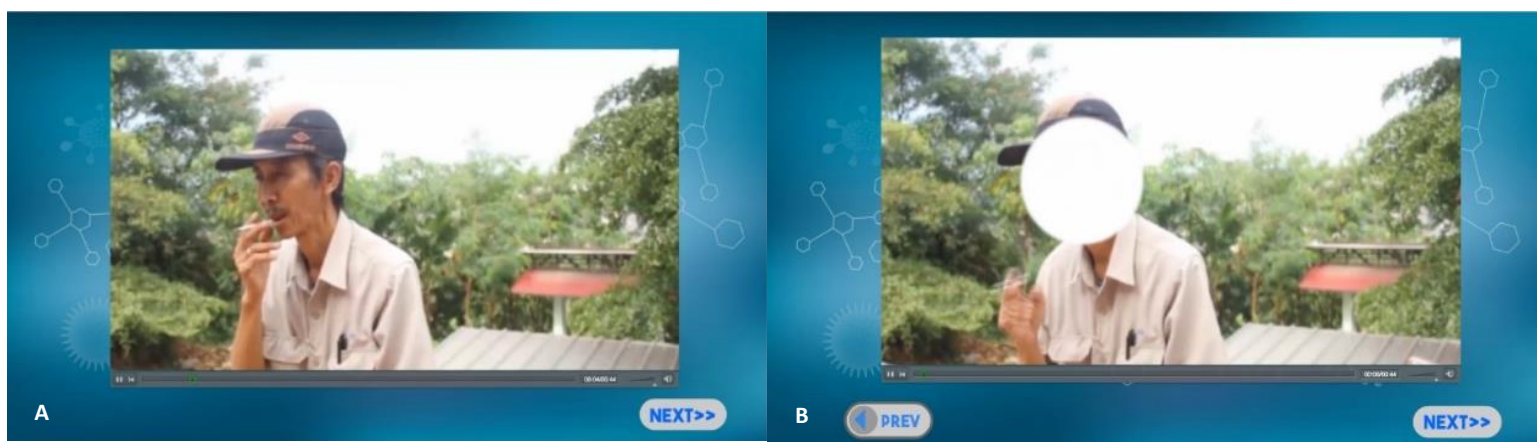

Figure 2. (A) Video problems (first prototype); (B) Video problems (final prototype) 
The first prototype in the menu section there are choices: (1) competency standards; (2) human respiration; (3) animal respiration; (4) quizzes; (5) info; and (6) exit (Figure 3-A). The final prototype in the menu section there are several revisions, as follows: (1) microscope images are replaced with images that match the learning material; (2) quiz is replaced with practice questions; and (3) added a new icon, namely "Did You Know?" (Figure $3-B)$. The first prototype in the display of human respiration there is a submenu consisting of: (1) respiration tools; (2) respiration process; (3) respiration illness; (4) respiration volume; and (5) cigarettes. In this section, there is also a video that shows the process of inspiration and expiration in chest and abdominal breathing. Each submenu has audio that is adjusted to the writing on the screen (Figure 4-A). The final prototype in the human respiratory system section there are several revisions, as follows: (1) submenus is simplified into four submenus, namely the respiration tool, respiration mechanism, respiration and cigarettes; (2) the background color of each slide varies; and (3) pictures adapted to relevant references (Figure 4-B).

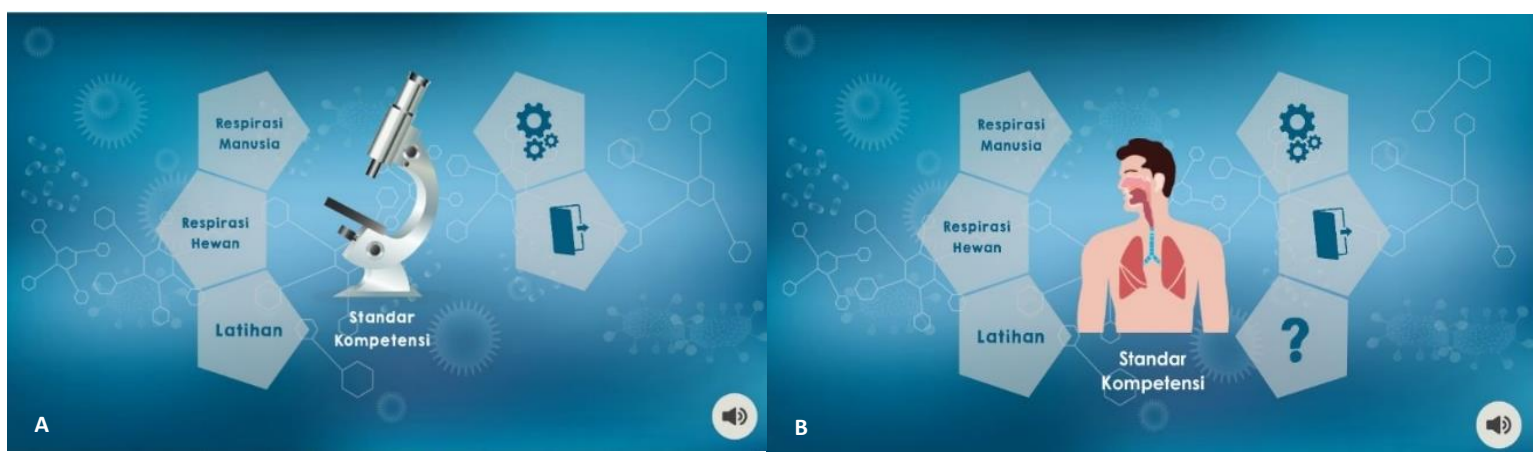

Figure 3. (A) Menu (first prototype); (B) Menu (final prototype)

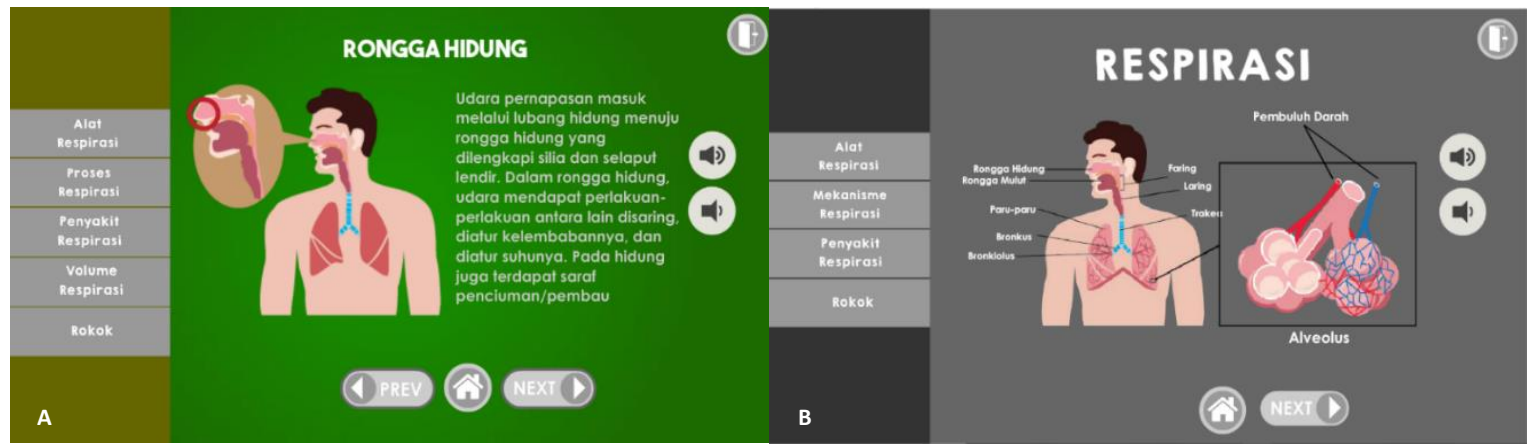

Figure 4. (A) Human respiratory system (first prototype); (B) Human respiratory system (final prototype)

The first prototype, there is no display of general knowledge. The final prototype, in the general knowledge section, it contains events that often occur in everyday life related to the respiratory system in humans. It means students master not only the concept but also the application (Figure 5). The first prototype in the display of the animal respiratory system section there is submenu Protozoa, Porifera \& Coelenterata, Worms, Mollusca \& Echinoderms, Arthropods, Pisces, Amphibians, Reptiles, and Aves. On each submenu, it is accompanied by audio that is adjusted to the writing on the screen (Figure 6-A). The final prototype in the animal respiratory system section, there is a simplification of the material, which is adapted to the biology syllabus of class XI, which is only insects and birds. However, the discussion is more profound than before (Figure 6-B).

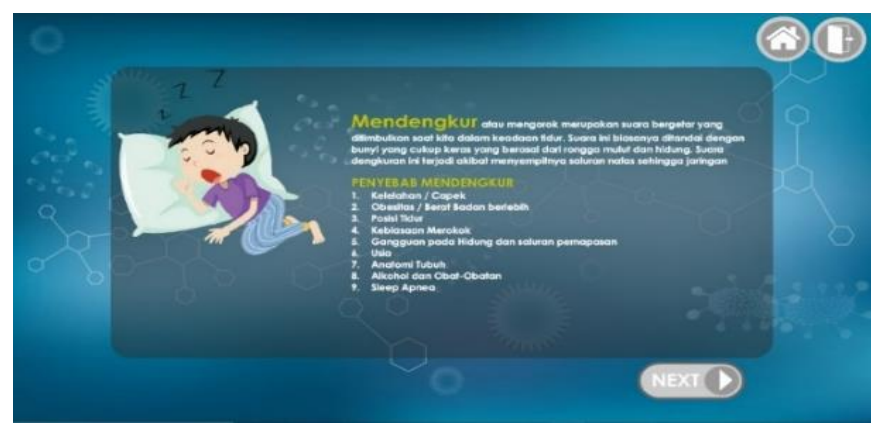

Figure 5. General knowledge 


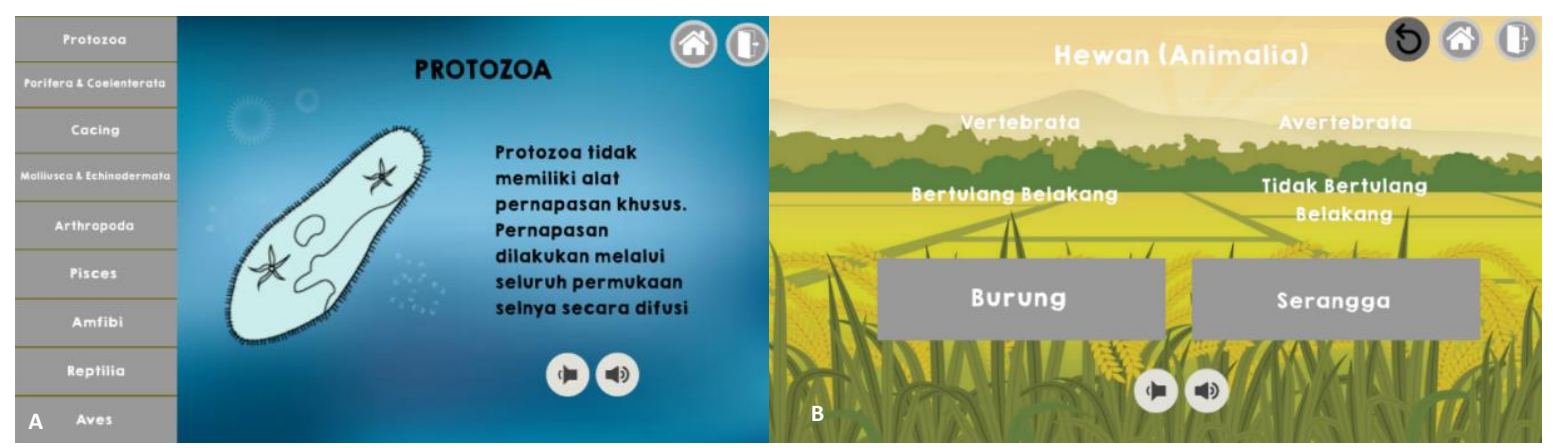

Figure 6. (A) Animal respiratory system (first prototype); (B) Animal respiratory system (final prototype)

The first prototype in the display of the practice section, some questions contain the material in the previous section. The items provided are ten questions with four answer choices. In this section, students can choose one correct answer. If the answer is correct, a value of 10 is given, whereas if the answer is wrong, the value is 0 (Figure 7-A). The final prototype in the practice section, some questions that are not related to the material, are replaced with other questions (Figure 7-B).

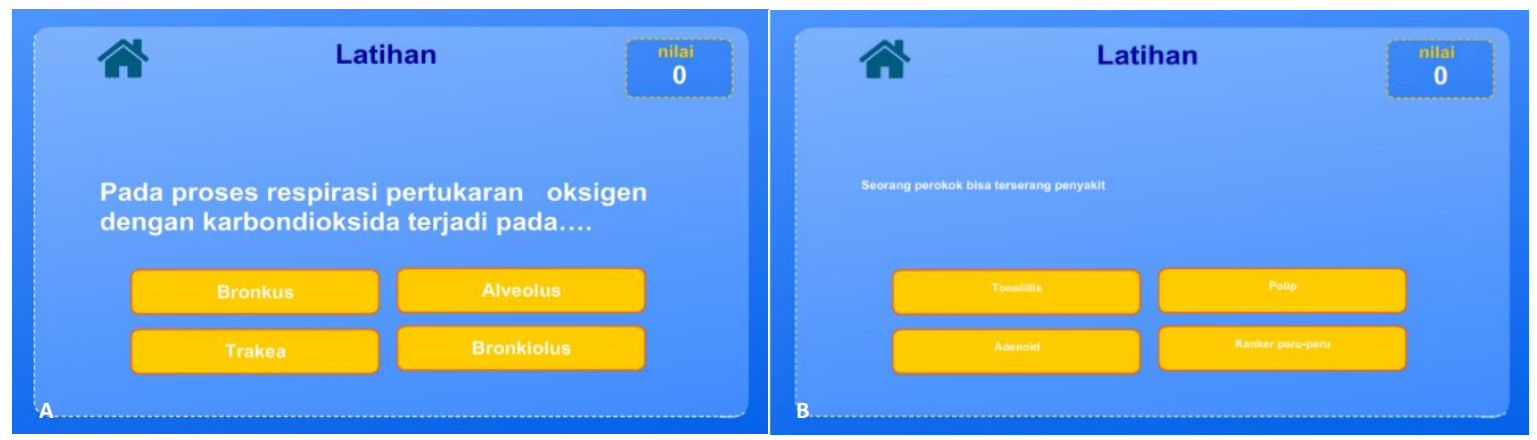

Figure 7. (A) Practice questions (first prototype); (B) Practice questions (final prototype)

After the first prototype was completed, expert validation was carried out. The experts in this study consisted of one media expert, one language expert, and one material expert. These experts come from education practitioners who master their respective fields from three different universities. The results of the validation by the material expert (Figure 8), it can be seen that content quality has a value of $81.67 \%$, which indicates that the learning media is very good in terms of content. This is because the preparation of this learning media has been adapted to the learning material contained in the eleventh-grade biology syllabus about the respiratory system. The quality of the construct has a value of $80 \%$, which means that the learning media is very good in terms of its construction. It is according to Tang and Patrick (2018) it means that the learning media developed can be used to measure symptoms according to the symptoms that are defined.

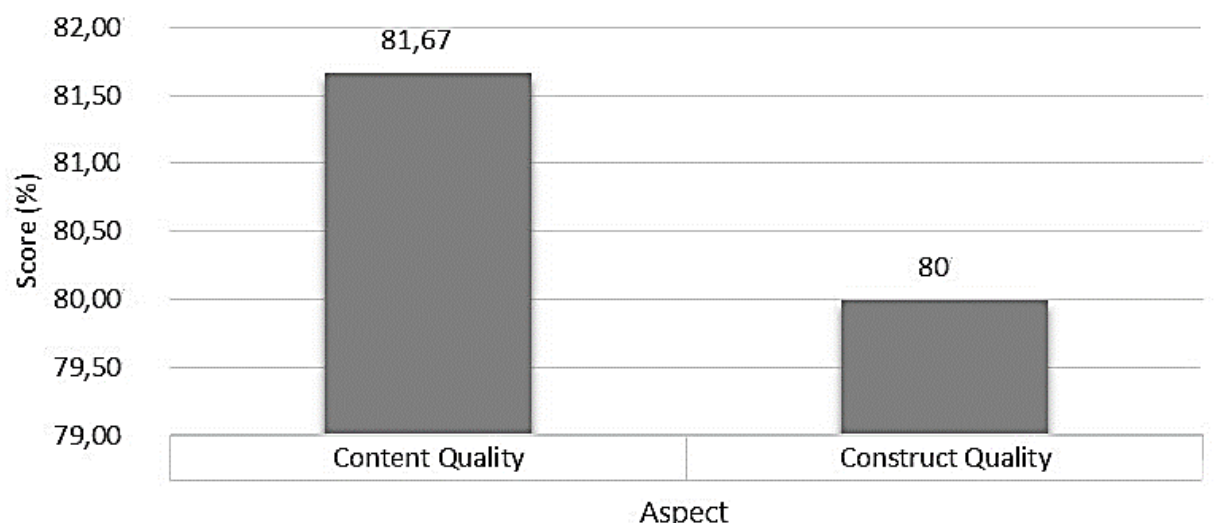

Figure 8. Content experts' judgment scores 
Overall an average value of $81 \%$ is obtained, which means that the learning media developed are very good. From the results of the validation by the material expert, there were also some inputs related to the material that needed to be revised for improvement. So, the conclusions obtained based on material expert validation are that learning media products are feasible to be developed with revisions according to input from material experts. Material expert give some comments including them: (1) the image on the slide must adjust to the material being discussed; (2) note the spacing; (3) in the larynx, images, and text do not match; and (4) enlarged nasal cavity images are replaced with more representative images.

After the learning media was revised according to expert advice, there was an increase in the value of the two aspects of the assessment (Figure 9). From the quality of the content, it initially scored $81.67 \%$ to $90 \%$, which was categorized as very good. Likewise, in the quality of learning (constructs) initially get a value of $80 \%$ to $90 \%$, which is categorized very well. So that the average final value has increased, initially $81 \%$ to $90 \%$, which is categorized as very good. Material expert give some comments including them: (1) note the suitability of the sound with the text; (2) correct the diffusion and pleural pronunciation; and (3) correct the order of the respiratory tract (lungs not mentioned between the bronchi and alveoli).

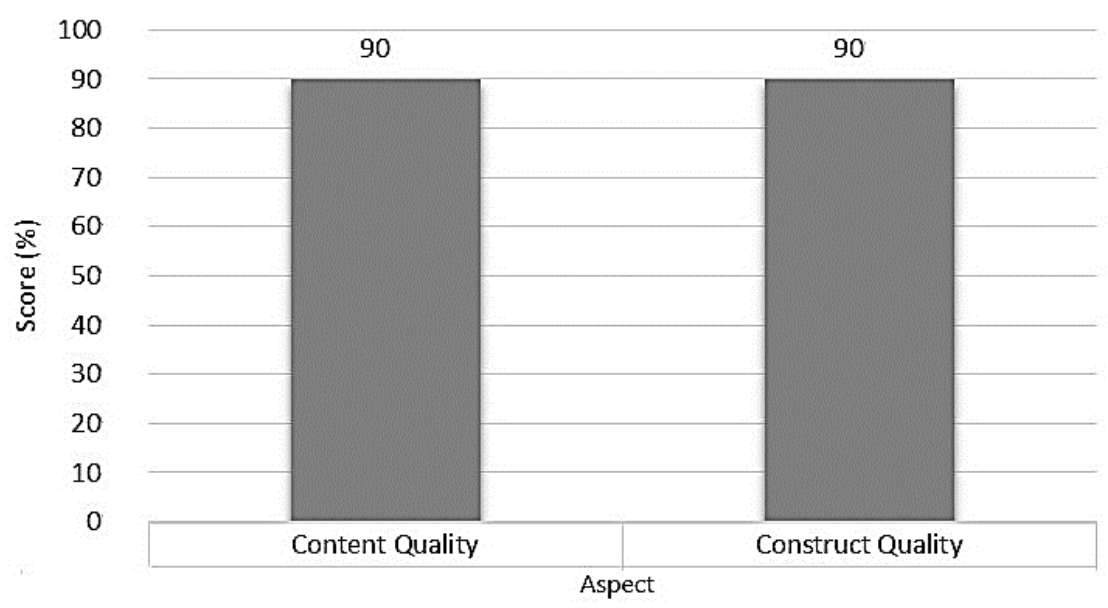

Figure 9. Content experts' judgment scores after revise

The results of the validation by a media expert (Figure 10), the visual appearance obtained is $82 \%$, which means that the learning media is very good. It means that the selection of text, letters, and images, in general, has been very good. Some notes in terms of the visual appearance of media experts include the use of more enlarged letters, the selection of images in some parts must be adjusted to the material, and sound clarity in some parts need to be corrected. In terms of programming, $80 \%$ is obtained, which means the program has been very well made. Some notes that need to be considered include a number of button buttons that still don't work and some symbols that have not been given information. In general, the results of evaluations by media experts get $81 \%$, which means very good. Media expert give some comments including them: (1) add a home menu to each slide; (2) add the button back to the initial page; (3) audio must be muted when moving to the next slide; (4) in the exercise section, add numbers and answer choices; and (5) the picture in the main menu section must match the material.

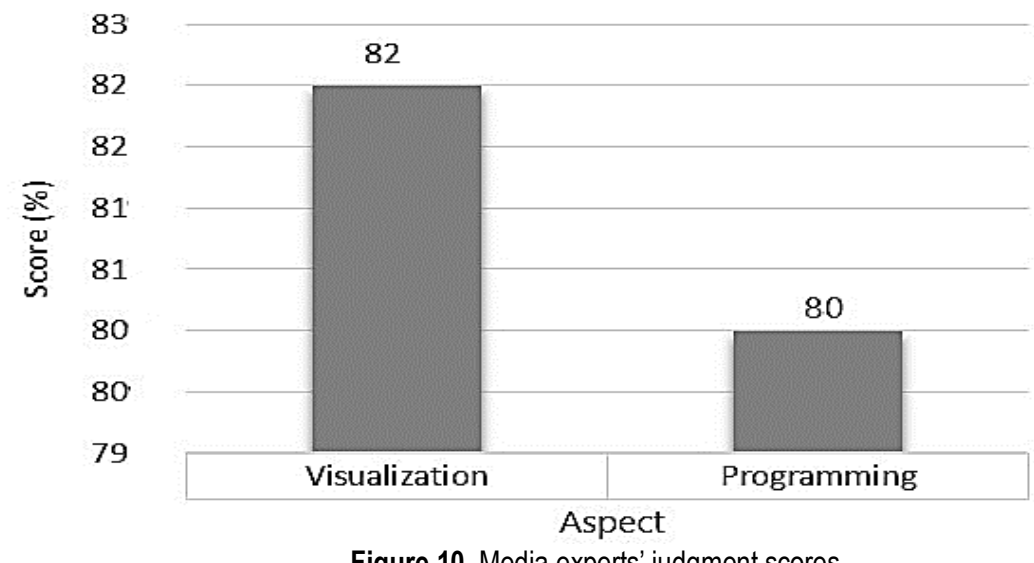

Figure 10. Media experts' judgment scores 
After the learning media was revised according to expert advice, it can be seen that there is an increase in the value of the aspect of media display and programming (Figure 11). In the aspect of media display, there was an increase of $82 \%$ (very good) to $84 \%$ (very good). In the programming aspect of the value of $80 \%$ (very good) to $82 \%$ (very good). Overall, an increase in value from $81 \%$ (very good) to $83 \%$ (very good). So that it can be concluded based on media experts, interactive learning media respiratory system that was developed very well and can be used in learning. Media expert give comments, including them improve audio quality on some material.

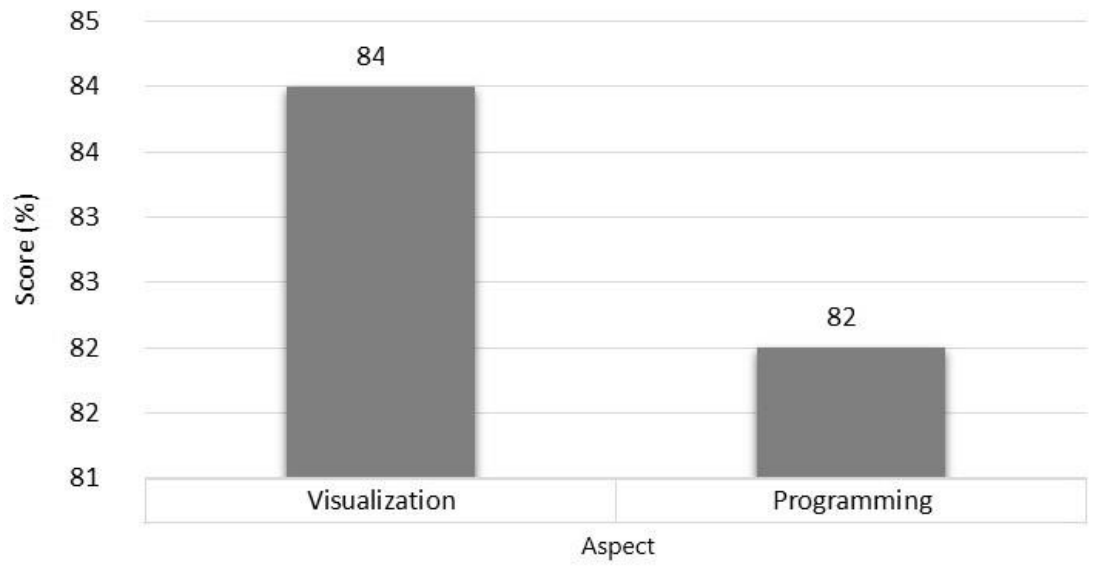

Figure 11. Results of learning media validation by media experts after revision

The results of the assessment by language expert (Figure 12) got many aspects that have received a value of $100 \%$, which means very good. Aspects that got a score of $100 \%$, among others sentence clarity, sentence readability, dialogic and interactive, straightforward, communicative, use of language that is in accordance with student development, font size and shape, and sequence presentation. It is because the use of language in this learning media has been adapted to the enhanced spelling in Indonesian. Overall, the language aspect of the interactive learning media developed has a score of $96 \%$, which means it is very good. The language expert give comments, including the use of language, is good and consistent.

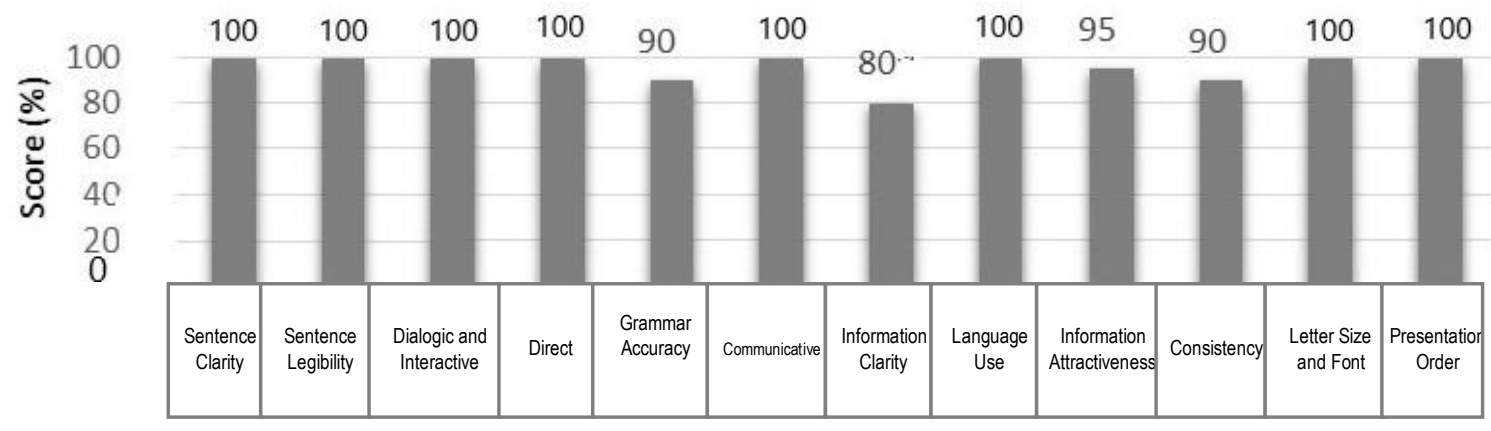

Figure 12. Language experts' judgment scores

After the learning media was revised according to language expert (Figure 13), there is an increase in conformity in the use of good and correct language. Based on the results of the assessment, an increase in value from $96 \%$ (very good) to $99 \%$ (very good). Therefore interactive learning media respiratory systems developed very well and can be used in learning. The language expert gives comments, including the use of language, is getting better and more consistent.

After validation by experts, input for the development of interactive learning media of the respiratory system also came from teachers (Figure 14). Based on the data obtained, the highest aspect is the ease of use and the ability to improve critical thinking, which is equal to $100 \%$. It is because the navigation buttons used are selected that are attractive and easy to use, and the problem video section that is displayed at the beginning and "Do you know?" It can stimulate students' critical thinking skills. This is in accordance with the opinion of Negovan, Sterian, and Colesniuc (2015) which states that someone who thinks critically will see problems from 
various sides and can produce solutions to these problems. According to Beltramo (2017) they use their imagination to think about the various possibilities that arise from the problems faced, then will plan a solution. The average overall score of teacher responses is $80 \%$, which is categorized as very good.

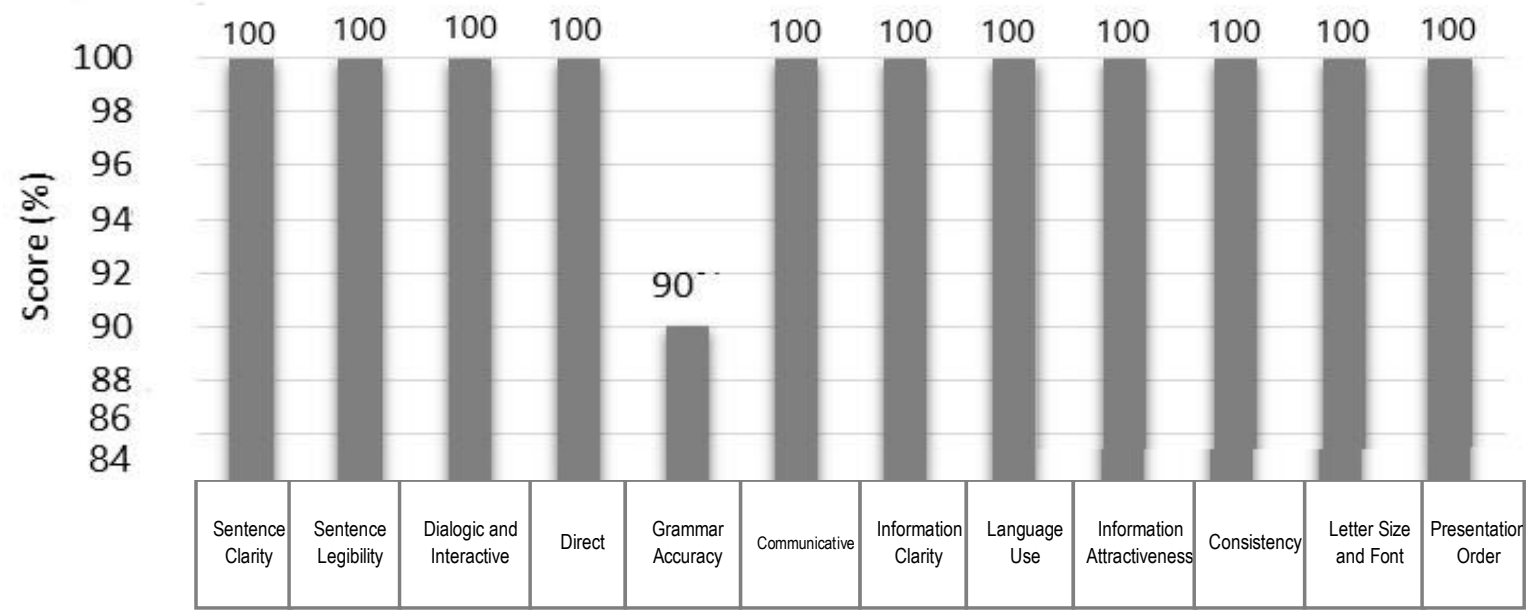

Figure 13. Results of learning media validation by linguists

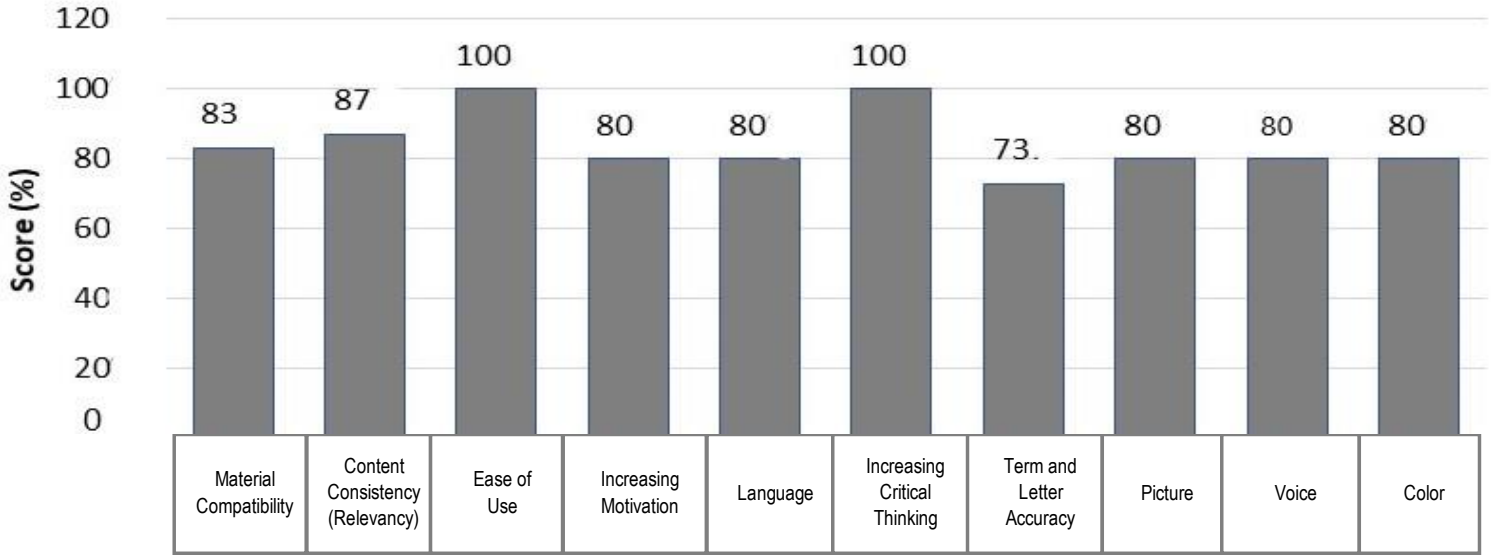

Figure 14. Teacher's response

Input for the development of interactive learning media of the respiratory system also came from response of students (Figure 15). Based on the data, it can be seen that the highest aspect is the use of language, which is equal to $98 \%$, with very good criteria. It is because the use of language in this media has been adapted to the standard spelling of the Indonesian language, and adjusted to the level of understanding of high school class XI students. The average value of the overall response of students is $89 \%$, which is categorized as very good.

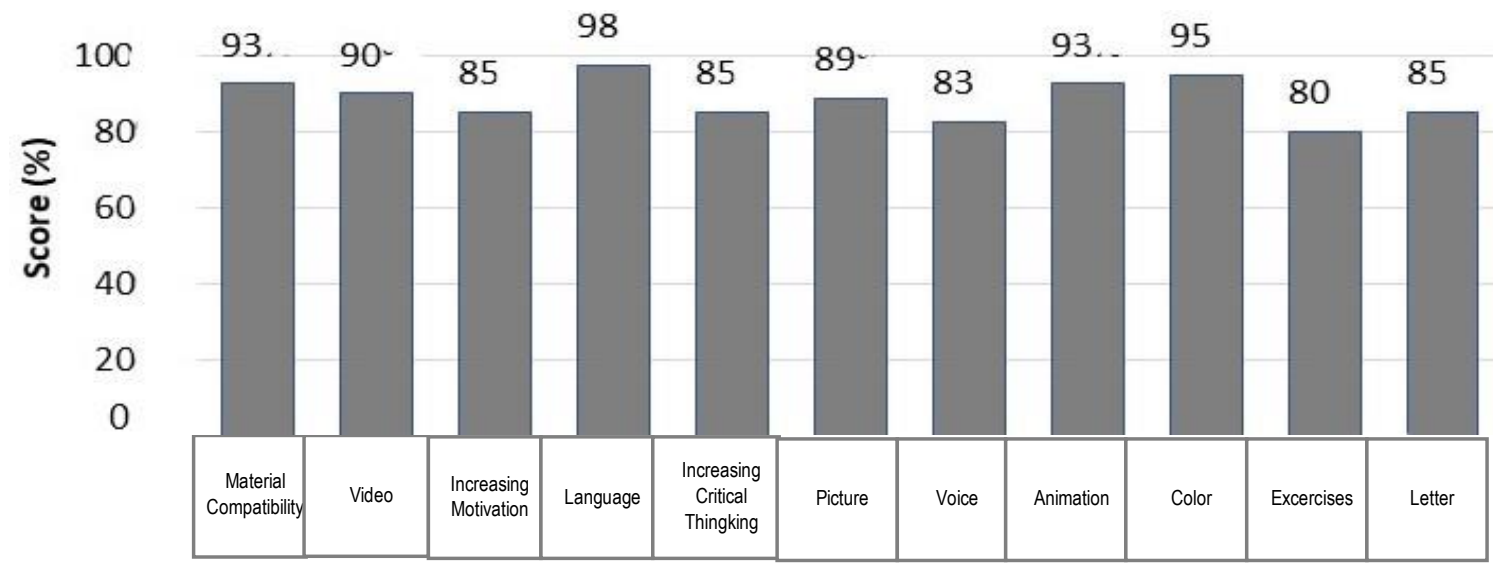

Figure 15. Students' responses 
In addition, learning that uses multimedia-based learning media can improve learning effectiveness, this is because with the use of technology, especially interactive learning media, teachers can optimize learning because it reduces or shortens the delivery time of materials, improves students' ability to solve problems, and improves performance of students (Anderson \& Davidson, 2019; Dring, 2019). In addition, to improve the ability of students, the use of interactive audio-based learning media can also improve teacher teaching competencies (Astra et al., 2015; Lobb, Inman, \& Butler, 2004; Williams, 2004). Other research states that the use of technology-based learning media can also improve teaching and learning processes and develop active and creative learning (Rowan, McCourt, \& Beake, 2008).

The use of images, animations, and videos can increase students' sense of interest, and learning motivation and learning effects are easier captured by students (Boa, Wattanatorn, \& Tagong, 2018; Donnelly, 2010). It is because the media has attractive colors, equipped with sound so that students are not saturated with reading. Based on the result of Negovan, Sterian, and Colesniuc (2015), students who have high motivation will have a stronger learning concept. Students will understand that learning is about a process of social development, selfchange, and is an ongoing process and is a task that must be carried out.

The use of animation on learning media can also facilitate students in understanding learning material (Burns, 2005; Chiang \& Fung, 2004; Nurbaiti, Panjaitan, \& Titin, 2017). It is also expected that with the involvement of students in the use of media, it will improve the learning outcomes of students. As the results of research from Rahmawati (2018) which states that the use of instructional media involving students can improve student learning outcomes. Based on Dunn and Kennedy (2019), the use of technology in learning can increase learning motivation which will certainly improve student learning outcomes. Especially in biology, interactive learning media is needed. As the results of research from Yusnaeni, Lika, and Hiul (2019) which state that the use of learning media as a learning resource can clarity and facilitate learners in learning activities, increase learning motivation, including the success of learning biology.

\section{CONCLUSION}

The results of this study indicate that media resysmart based on interactive problem-based learning for use on respiration system material. This can be proven from the results of validation results from material experts, media experts and linguists state that this interactive learning media is very good. The response of teachers and students states that this interactive learning media is very good. This interactive learning media is expected

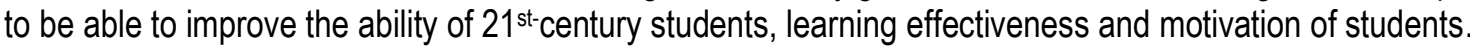

\section{ACKNOWLEDGMENT}

Acknowledgments are addressed to those who have assisted in this research, especially state senior high school (SMAN) 3 Cibinong as a place for testing learning media, animators for making learning media and linguists, media and material on the respiratory system.

\section{REFERENCES}

Agustina, K., Kristiyanto, W. H., \& Noviandini, D. (2017). Learning design of problem based learning model based on recommendations of sintax study and contents issues on physics impulse materials with experimental activities. Scientific Journal of Universitas Negeri Semarang, 2(2), 68-81. doi: https://doi.or g/10.15294/ijal.v2i2.10802

Allison, P., Gray, S., Sproule, J., Nash, C., Martindale, R., \& Wang, J. (2015). Exploring contributions of projectbased learning to health and wellbeing in secondary education. Improving Schools, 18(3), 207-220. doi: https://doi.org/10.1177/1365480215599298

Anderson, D. R., \& Davidson, M. C. (2019). Receptive versus interactive video screens: a role for the brain's default mode network in learning from media. Computers in Human Behavior, 99, 168-180. doi: https:// doi.org/10.1016/j.chb.2019.05.008

Astra, I. M., Nasbey, H., \& Nugraha, A. (2015). Development of an android application in the form of a simulation lab as learning media for senior high school students. EURASIA Journal of Mathematics, Science \& Technology Education, 11(5), 1081-1088. doi: https://doi.org/10.12973/eurasia.2015.1376a 
Beemt, A., Akkerman, S., \& Simons, R. J. (2011). Considering young people's motives for interactive media use. Educational Research Review, 6(1), 55-66. doi: https://doi.org/10.1016/j.edurev.2010.06.002

Beltramo, J. L. (2017). Developing adaptive teaching practices through participation in cogenerative dialogues. Teaching and Teacher Education, 63, 326-337. doi: https://doi.org/10.1016/j.tate.2017.01.007

Boa, E. A., Wattanatorn, A., \& Tagong, K. (2018). The development and validation of the blended socratic method of teaching (BSMT): an instructional model to enhance critical thinking skills of undergraduate business students. Kasetsart Journal of Social Sciences, 39(1), 81-89. doi: https://doi.org/10.1016/j.kjss. 2018.01.001

Borg, W. R., \& Gall, M. D. (1983). Educational research: an introduction. London: Longman Inc. Retrieved from https://bit.ly/36LUUPf

Burns, B. (2005). Utilising information technology and problem-based learning strategies to resolve practice dilemmas in a children's orthopaedic setting. Journal of Orthopaedic Nursing, 9(3), 127-133. doi: https:// doi.org/10.1016/j.joon.2005.07.003

Chen, N. C. (2008). An educational approach to problem-based learning. The Kaohsiung Journal of Medical Sciences, 24(3), 23-30. doi: https://doi.org/10.1016/S1607-551X(08)70090-1

Chiang, A. C. C., \& Fung, I. P. W. (2004). Redesigning chat forum for critical thinking in a problem-based learning environment. The Internet and Higher Education, 7(4), 311-328. doi: https://doi.org/10.1016/j.ihe duc.2004.09.006

Copenhaver, A., \& Ferguson, C. J. (2018). Selling violent video game solutions: a look inside the apa's internal notes leading to the creation of the apa's 2005 resolution on violence in video games and interactive media. International Journal of Law and Psychiatry, 57, 77-84. doi: https://doi.org/10.1016/j.jip.2018.01. 004

Donnelly, R. (2010). Harmonizing technology with interaction in blended problem-based learning. Computers \& Education, 54(2), 350-359. doi: https://doi.org/10.1016/j.compedu.2009.08.012

Dring, J. C. (2019). Problem-based learning experiencing and understanding the prominence during medical school: perspective. Annals of Medicine and Surgery, 47, 27-28. doi: https://doi.org/10.1016/j.amsu.2019. 09.004

Dunn, T. J., \& Kennedy, M. (2019). Technology enhanced learning in higher education; motivations, engagement and academic achievement. Computers \& Education, 137, 104-113. doi: https://doi.org/10. 1016/j.compedu.2019.04.004

Gao, B., \& Huang, L. (2019). Understanding interactive user behavior in smart media content service: an integration of tam and smart service belief factors. Heliyon, 5(12). doi: https://doi.org/10.1016/j.heliyon.20 19.e02983

Harris, A. T., \& Andrews, S. B. (2008). Development of a problem-based learning elective in "green engineering." Education for Chemical Engineers, 3(1), 15-21. doi: https://doi.org/10.1016/j.ece.2007.12.001

Hong, H. Y., Lin, P. Y., \& Lee, Y. H. (2019). Developing effective knowledge-building environments through constructivist teaching beliefs and technology-integration knowledge: a survey of middle-school teachers in northern Taiwan. Learning and Individual Differences, 76. doi: https://doi.org/10.1016/j.lindif.2019. 101787

Kerkhoff, S. N. (2017). Designing global futures: a mixed methods study to develop and validate the teaching for global readiness scale. Teaching and Teacher Education, 65, 91-106. doi: https://doi.org/10.1016/j.ta te.2017.03.011

Klunklin, A., Subpaiboongid, P., Keitlertnapha, P., Viseskul, N., \& Turale, S. (2011). Thai nursing students' adaption to problem-based learning: a qualitative study. Nurse Education in Practice, 11(6), 370-374. doi: https://doi.org/10.1016/j.nepr.2011.03.011

Lau, H. Y. K., \& Mak, K. L. (2004). The virtual company: a re-configurable open shell for problem-based learning in industrial engineering. Computers \& Industrial Engineering, 47(2), 289-312. doi: https://doi.org/10.1016 j.cie.2004.08.002

Liu, L., Du, X., Zhang, Z., \& Zhou, J. (2019). Effect of problem-based learning in pharmacology education: a meta-analysis. Studies in Educational Evaluation, 60, 43-58. doi: https://doi.org/10.1016/j.stueduc.2018. 11.004

Lobb, D. K., Inman, D. R., \& Butler, R. G. (2004). Problem-based learning in reproductive physiology. Journal of Midwifery \& Women's Health, 49(5), 449-453. doi: https://doi.org/10.1016/j.jmwh.2004.04.014

Mason, R. (2006). Literacy in the digital age. British Journal of Educational Technology, 37(2), 307-317. doi: https://doi.org/10.1111/j.1467-8535.2006.00602_10.x 
McAlpine, I., \& Clements, R. (2001). Problem based learning in the design of a multimedia project. Australasian Journal of Educational Technology, 17(2), 115-130. doi: https://doi.org/10.14742/ajet.1786

Miklos, V. F. C. . (2019). Fifty years on: a retrospective on the world's first problem-based learning programme at McMaster University Medical School. Health Professions Education, 5(1), 3-12. doi: https://doi.org/10.1 016/j.hpe.2018.04.002

Negovan, V., Sterian, M., \& Colesniuc, G. (2015). Conceptions of learning and intrinsic motivation in different learning environments. International Conference PSIWORLD 2014-5th Edition, Procedia - Social and Behavioral Sciences, 187, 642-646. doi: https://doi.org/10.1016/j.sbspro.2015.03.119

Nurbaiti, N., Panjaitan, R. G. P., \& Titin, T. (2017). The properness of adobe flash basis interactive media for respiratory system learning material. Unnes Science Education Journal, 6(3), 1662-1668. doi: https://doi. org/10.15294/usej.v6i3.20350

Rahmawati, A. (2018). The use of computer-based interactive game to make the imaginary logic of structural analysis more real. Journal of Turkish Science Education, 15, 1-12. doi: https://doi.org/10.12973/tused.10 $251 \mathrm{a}$

Rowan, C. J., McCourt, C., \& Beake, S. (2008). Problem based learning in midwifery - the students' perspective. Nurse Education Today, 28(1), 93-99. doi: https://doi.org/10.1016/j.nedt.2007.02.014

Sudijono, A. (2005). Pengantar statistik pendidikan. Jakarta: PT Raja Grafindo Persada. Retrieved from https:// bit.ly/2tY9xAa

Tang, S., \& Patrick, M. E. (2018). Technology and interactive social media use among 8th and 10th graders in the U.S. and associations with homework and school grades. Computers in Human Behavior, 86, 34-44. doi: https://doi.org/10.1016/j.chb.2018.04.025

Tran, T. B. L., Ho, T. N., Mackenzie, S. V, \& Le, L. kim. (2017). Developing assessment criteria of a lesson for creativity to promote teaching for creativity. Thinking Skills and Creativity, 25, 10-26. doi: https://doi.org/ 10.1016/j.tsc.2017.05.006

Ward, K., \& Hartley, J. (2006). Using a virtual learning environment to address one problem with problem based learning. Nurse Education in Practice, 6(4), 185-191. doi: https://doi.org/10.1016/j.nepr.2005.12.003

Williams, B. (2004). Self direction in a problem based learning program. Nurse Education Today, 24(4), 277285. doi: https://doi.org/10.1016/j.nedt.2004.01.008

Wyness, L., \& Dalton, F. (2018). The value of problem-based learning in learning for sustainability: undergraduate accounting student perspectives. Journal of Accounting Education, 45, 1-19. doi: https:// doi.org/10.1016/j.jaccedu.2018.09.001

Yusnaeni, Y., Lika, A. G., \& Hiul, S. (2019). Human respiratory system: designing student worksheet based on inquiry to promote 21st-century skills. Biosfer: Jurnal Pendidikan Biologi, 12(1), 34-44. doi: https://doi.org /10.21009/10.21009/biosferjpb.v12n1.34-44

Zhang, W., Zheng, Q., Li, H., \& Tian, F. (2012). An overlay multicast protocol for live streaming and delayguaranteed interactive media. Journal of Network and Computer Applications, 35(1), 20-28. doi: https:/l doi.org/10.1016/j.jnca.2011.02.013 